\title{
The Necropolitics of Austerity: Discursive Constructions and Material Consequences in the Greek Context
}

\author{
Panayota Gounari
}

\section{Introduction}

The onset of the global capitalist crisis in 2008, brought about important shifts beyond the material plane. A crisis of capitalism can never be understood as simply an economic crisis; it is also, at its core, a political and ideological crisis. The ideological aspect of the crisis is further articulated through language, that is, through the use of particular discourses. Conservative think tanks and larger-than-life financial institutions have highjacked the mainstream narrative around the crisis and its consequences, and have changed the terms these crises are talked about and, therefore, understood.

In this article I am offering a critical discussion of the closing of the universe of discourse since the beginning of the capitalist crisis in the Greek context. In the framework of what is often projected as an anthropomorphist economy, I examine the discursive and material construction of "austerity" as it articulates with other supporting discourses: that of "markets as people," "sacrifice," and "living beyond one's means" as well as the discourse of "obedience/disobedience." The narratives around these concepts have largely shaped and distorted the debate around the Greek financial crisis. My argument is, once more, that the shift in language is not natural or neutral but it reflects, refracts and shapes a deeper shift in its framing and therefore, in policies/politics. Those institutions that have the power to produce politics and ideologies, have also the power to produce a "strong discourse" and, thus, have hegemony over that discourse.

The imposed cutthroat austerity in Greece the last seven years as a panacea for what has been touted the "overspending of the public sector" and for "tidying up the budget" has nothing to do with financial efficiency or even a viable economic plan for the Greek people. It has everything to do with an attempt of the autochthonous and global elites to maintain power and wealth, coupled with the increased authoritarianism and discipline in the European Union and the ongoing weakening of decision making of national governments/member states. In the name of the global financial interests of an oligarchy, EU leaders are quick to forget the "democratic" roots of "a peaceful, united and prosperous Europe" (The History of European Union) in order to promote a violent capitalist agenda under the guise of our "common European family." The limited autonomy in decision making for EU member-states became abundantly clear in the week after the "No" vote at the July 2015 referendum in Greece leading to the full capitulation and sellout of the Syriza government. At the time, top European officials intervened in the Greek public discourse, openly discrediting the result of the Greek referendum, even putting forth the idea of a regime change in Greece that would institute a complacent and servile government. Syriza capitulated quickly so they found their servants in Syriza's cabinet.

It is not an exaggeration to claim that Greece has been treated as a protectorate or a debt colony, where directives are communicated straight from Brussels and the headquarters of the European Central Bank (ECB). Granted, similar "coups" have taken place in many parts of Latin America and Africa before, wherever mega financial institutions such as the IMF have stepped in to "save" other countries at the edge of their "financial catastrophe." 
However, it is the first time that an EU member is being subject to such a "special treatment." For example, the list of demands that arose from the July 2015 Eurogroup in order to guarantee a new 86 billion Euros bailout for a nonviable debt - then at 177\% of the GDP (Flassbeck and Lapavitsas, 2015) were labeled a "catalogue of cruelties" by Der Spiegel Online, while Paul Krugman stressed that they go "beyond harsh into pure vindictiveness, complete destruction of national sovereignty and no hope of relief [...] a grotesque betrayal of everything the European project was supposed to stand for" (2015a). Along the same lines, Joseph Stiglitz called Germany's imposition of inefficient, counter-productive models that produce injustice and inequality not just punitive but of blind stupidity (Stiglitz, 2015).

This "catalogue of cruelties" that has been expanded during Syriza's first year in government, resonates a great deal with "necropolitics," or politics that promote death. These are in line with what I have termed elsewhere, in the context of neoliberalism, as "social necrophilia" (Gounari, 2014). More specifically, the neoliberal experiment, as implemented in Greece, that breeds destructiveness and death, can be understood as a form of "social necrophilia"; By that I mean the blunt organized effort on the part of the domestic political system and foreign neoliberal centers to implement economic policies that result in the physical, material, social and financial destruction of human beings: policies that promote death, whether physical or symbolic. The goal of the ongoing unprecedented austerity measures in Greece is to destroy physically and symbolically the most vulnerable strata of the population, to put the entire society in a moribund state, in order generate profit for the most privileged classes internationally. Without succumbing to a discourse-centered analysis that would over-celebrate language over the material conditions and supplant social events (Holborow 2015) I am offering here a critical approach on those discourses and narratives that have dressed the policies of death with progress, development, entrepreneurialship, and other neoliberal terms systematically used to build the neoliberal fairy tale.

\section{| The Rise of "Economese"}

In the last seven years we have been observing what Marcuse has called "the closing of the universe of discourse" (Marcuse, 1964) where language, neutralized and purged of its historical meanings and significations, has been operationalized in the service of capitalist significations. Dominant capitalist discourses militate against the development of meaning, as "natural" and "neutral" codes are now used to talk about material and symbolic violence in the most innocent and non-threatening way. Marcuse (1964) correctly noted that "language tends to express and promote the immediate identification of reason and fact, truth and established truth, essence and existence, the thing and its function" (p. 85). More importantly, this constructed neoliberal-dominated universe of discourse closes itself against any other discourse that is not on its own terms.

A typical characteristic of any emerging neoliberal state is the rise of "economese," that is, technical language inspired from Economics that has penetrated the public discourse and is used with pre-given and self-evident meanings to justify economic policies. Economese is a "common sense" discourse that limits the universe of discourse and re-routes language in the service of the capitalist order, therefore obstructing people's capacity to question its meaning and content. Economese has become since 2008 part of Greek mainstream discourse in an almost natural and seamless way. Words like bailout, default, memoranda of understanding, CDS, haircut, restructuring, government bonds and so forth, found their way into mainstream discourses. They invaded television screens, newspaper articles, blogs, analyses, almost every realm of public and private discourse. Politicians, intellectuals, journalists and other public figures_what Fromm (1981) calls "political priests" — who shape public opinion and alter collective consciousness, have emerged promptly to provide their services to the new economic and political order using a well-crafted discourse to administer "the idea of freedom to protect the economic interests of their social class. The priests declare that people are not capable of being free and take over ideas and decide how they will be formulated" (Fromm, 1981, p.17). These political priests are the guarantors of consensus since they are the ones feeding and promulgating the new economese to the public.

Krugman (2013) admits that "economese may sound like English [or any other language for that matter], but it sometimes has crucial differences" and confusion often arises "from the way economists use words. Fairly often, we have a term of art that is pretty deeply embedded in the professional discourse, but which either sounds strange to outsiders or can be misinterpreted" and he concludes "it's ultimately not about the words — it's about the model." Krugman is right about the misinterpretation, or rather, the re-framing of words taken from professional discourses 
when they are used outside of their intended context. But contrary to his last claim, I believe that it is as much about the words as it is about the model. Words as constituents of discourses often create a new model through a strong discourse, one that bears no relevance to the original technical term; and in turn, any model needs to be represented and framed through words. In addition, there is historicity in the terms we use, both in a synchronic and diachronic way: word definitions always come with a "historical burden" but words often shift meanings in given historical and political contexts. The problem with neoliberal economese is that it appropriates financial terms in order to create a mainstream language by stripping words from their history and historically-shaped meanings. For example, the use of the word "market" has taken a life (of significations) of its own in neoliberal economese. These days the "market" whether used as a noun, subject or object, is projected as an overarching authority, above and beyond everybody, a self-evident entity that should be kept happy and satisfied. Markets are personified and they have acquired "the status of living, breathing humans" ... "omnipotent, adversarial, autonomous, intensely unpredictable, and in a position to dictate at will what should happen and what exact policies should be adopted" (Holborow, 2015, pp. 35-36). The anthropomorphism of the market is illustrated when markets are used in the mainstream media in sentences such as "the markets showed satisfaction today" or "the market is struggling," and "we need to convince the markets," "we should appease the markets" or "let's wait and see how the markets respond." One could also read impressive lines to that effect in news media inspired by the 2015 Greek referendum such as "it is difficult to tell what the markets are dancing: ballet, tsamiko or tsifteteli," "why the markets did not contract the Greek flu" and "markets are worried about the Grexit scenario." The invisible market's "reactions" give legitimacy to the "human sacrifices," as all "market feelings" depend on increasing anti-social and counterproductive austerity measures that relegate a large part of Greek productive population to the unemployment trashcan. Beyond all the mythology about self-regulation and naturalness of a highly economic realm, real markets are definitely not people, they have no feelings and they are highly political. As Karl Polanyi noted at the end of World War II, there is nothing natural about markets. They are constituted of "systems of rules and regulations made and enforced by both state and non-state agencies, including market actors themselves" (Leys, 2001, p.3). Markets are complex, they are typically linked to wide range of other markets and they are also "embedded' [...] in a vast range of other social relations" finally, they are inherently unstable, from the nature of competition itself" (Leys, 2001, p. 3).

The more human qualities are attributed to the markets, the more real people are robbed off their own human substance and agency, even though neoliberal discourses are trying to argue for the opposite. It seems as if the system needs to dehumanize people in order to "humanize" the economy, the markets, the banks or other financial institutions. People become unalive things and the market becomes alive. This purposeful operation on the part of the powerful elites can be understood as the process of creating a neoliberal subject as human capital in the context of capitalism. As Richard Seymour notes, "neoliberals recognize that human beings are not necessarily predisposed to embrace 'the market' [...] People must be compelled to embrace their 'entrepreneurial' selves, to treat every aspect of their lives as a self-maximizing quest, and to embrace the calculus of risks and rewards in the market, including the inequalities that come with it, rather than seeking to control it" (Seymour, 2014, p. 9).

While people become things, things, in turn, become "people." People are slowly losing their humanity as they transition into "neoliberal subjects" with the government abandoning its social and welfare functions, and at the same time economic entities are becoming the new referent people should care and worry about. Economic institutions while being lifeless things, are acquiring a soul and a character in the neoliberal discourse. One can observe an interesting phenomenon in the official government discourse, loyally reproduced by mainstream media: a continuous attempt to ascribe human properties to financial institutions. This is along the lines of administering "things and men as one" (Fromm 1963, p. 22). This anthropomorphism is illustrated in the 2010 ruling of the U.S. Supreme Court in Citizens United v. Federal Election Commission that corporations are people, upholding the rights of corporations to unlimited corporate and union spending on political issues under the First Amendment. The U.S. Supreme Court endorsed corporate personhood holding that business firms have rights to religious freedom under federal law. Not only do corporations have rights, their rights are often stronger than people's rights. The same idea was echoed in republican presidential hopeful Mitt Romney's statement in 2012, that "Corporations are people, my friend!'[1] to which Robert Reich, Berkeley professor and former Secretary of Labor countered "I'll believe corporations are people when Texas executes one."

Language is used in the capitalist context as a vehicle for re-naming the ongoing shift of the state from human welfare to market welfare (Gounari 2006, 2012). It is not a coincidence that the current austerity measures in Greece are promoted under the umbrella of restructuring, reform, improvement, progress and streamlining of an inherently problematic system. However, these structural changes and reforms are, in essence, the epitome of deregulation 
and/or ways of facilitating investment for foreign companies, privatizations, release of any state controls and out-ofcontrol economic development that has only one goal: accumulation of wealth and interest for the global financial capital. This language also supports the conscious attempt on the part of dominant ideologies to package austerity measures in such way that hides the fact that the real beneficiaries are, in fact, foreign investment capital, banking and financial organizations and not the Greek people. For instance, only a small fraction (less than 10\%) of the 240 billion Euros total bailout money Greece received in 2010 and 2012 went into the government's coffers to address the 2008 financial crash and to fund reform programs. Most of the money went to the banks that lent Greece funds before the crash (Inman, 2015).

\title{
| The Discursive Construction of Austerity versus "Litotita"
}

\author{
"There is little doubt that [austerity] is an economy that is basically killing itself"
} - (Fleissbeck and Lapavitsas, 2015, p. 239)

Economic austerity can be safely labeled as one of the most fatally flawed "economic ideas" of the century. There is really no well worked out "theory of austerity" in economic thought. Austerity simply does not work (Blyth, 2013; Krugman 2015; Semour 2015). It is a "delusion" (Blyth, 2013; Krugman 2015) and a "strange malady" (Krugman, 2015) since its policies are "more often than not exactly the wrong thing to do precisely because [they] produce the very outcomes you are trying to avoid” (Blyth, 2013, p. 14). As Blyth puts it,

\begin{abstract}
Austerity is a form of voluntary deflation in which the economy adjusts through the reduction of wages, prices, and public spending to restore competitiveness, which is (supposedly) best achieved by cutting the state's budget, debts, and deficits. Doing so, its advocates believe, will inspire "business confidence" since the government will neither be "crowding-out" the market for investment by sucking up all the available capital through the issuance of debt, nor adding to the nation's already "too big" debt" (p. 14).
\end{abstract}

Austerity's central idea is that states cannot spend more than they take in, so, in order to balance their deficit budgets, they need to reduce spending while increasing taxes and cutting pensions and salaries. Greece, for instance, was forced to reduce its deficit by transferring the cost to pensioners, welfare recipients and salaried workers. As Holborow notes, "proceeding from the logic of translating private debt into social debt, austerity socializes the crisis by calling on the whole of society to make cutbacks. Austerity reinforces a concealment of the original causes of the crisis, vividly illustrating the tight cross-over between ideology and language" (Holborow, 2015, pp. 96-97).

Clearly, austerity implemented in an already depressed and weakened economy can only push it deeper into depression and delay, if not prevent altogether any signs of recovery so why is it still projected as an optimal solution? Given that financial crises have nothing to do with states and everything to do with markets, why are citizens called to pay for the markets' crisis? The answer to these questions is straightforward: austerity, the way it has been implemented, has nothing to do with the economy. Austerity is the implementation of neoliberal necroeconomics under the guise of an economic "theory." What we have in place in the context of a violent capitalism is a broader "shift in the entire civilizational edifice of capitalism" (Seymour 2014, p. 3). Drawing on Seymour's work I want to make the case that this shift includes but is not limited to the following:1 a) the reorganization/regrouping of the elites since the system they have copiously put in place and operate is at risk, and the "recomposition of social classes with more inequality and more stratification" b) the shift from the welfare state to the militarized and corporatized state that is increasingly taking on a punitive role, c) the creation of the neoliberal subject that, in turn, becomes part of a more competitive, highly hierarchical society that values "casual sadism toward the weak" d) "The growing strength of financial capital within capitalist economies and the accompanying spread of 'precarity' in all areas of life" (Seymour, p.3-4) and, finally, e) the shift in the ideological plane and away from the economy, as illustrated for example, in European Council leader Donald Tusk's statement to the Financial Times: "I am really afraid of this ideological or political contagion, not financial contagion, of this Greek crisis” (Der Spiegel, 2015).

Wherever austerity was implemented to address similar financial crises, it has failed miserably not only because there is no soundness to the theory but also because it has always moved along the interests of the ruling capitalist classes. While economic domination of the population is the end goal, and while real material strangleholds are suffocating Greek people, the twist of contemporary European politics is materialized on the political and ideological 
realm where one can witness a blunt, unapologetic, totalitarian stance that seeks to humiliate and discipline while subjugating on the economic realm.

As mentioned earlier, with the onset of the Greek financial crisis, mainstream language was injected with new financial terms that automatically took on given, predetermined meanings. As Doreen Massey notes, "the vocabularies which have reclassified roles, identities and relationships - of people, places and institutions - and the practices which enact them embody and enforce the ideology of neoliberalism, and thus a new capitalist hegemony $[\ldots]$ These definitions constitute another element of 'common sense' - about the way the economic world 'naturally' is and must remain" (Massey, 2013, p. 9)

The discourse of "austerity" is a way to talk about the economy in moral terms without talking about the human consequences — the real moral plane; these are simply collateral damage; they are invisible as are the people who suffer these consequences. In this way, the meaning and content of austerity is not simply reduced, it imposes limitations on the ways we think about it. Austerity was re-introduced into the Greek vocabulary in 2008, as part of the new neoliberal "economese." It instantly acquired momentum and, with it, a pre-given unquestioned meaning as it penetrated our language in a seamless, quiet and natural way. But once more, we did not know what we were talking about and yet we used it ad nauseam in the context of the Greek crisis, as something that needed to be done. Interestingly, austerity defined as "enforced or extreme economy" toped the 2010 search for words in Merriam Webster Dictionary's word of the year, as “people's attention was drawn to global economic conditions and the debt crises in Europe, but lookups also remained strong throughout the year, reflecting widespread use of the word in many contexts" according to the site (Merriam-Webster Dictionary Online 2015). "Austerity clearly resonates with many people," noted Peter Sokolowski, Editor at Large at Merriam-Webster, adding that "we often hear it used in the context of government measures, but we also apply it to our own personal finances and what is sometimes called the new normal" (Merriam-Webster Online). This statement underscores vividly the conflation of uses for a single word that has been uncritically accepted and used with different significations. Nations cannot and should not be run like households.

The construction and promulgation of a natural "austerity discourse" achieves three goals: First, it blurs the flaws of its purported "financial" soundness; second, it masks its human consequences; and third, it further strengthens the stereotype of "disobedient" Greeks. There is an interesting semantic game at play here: Austerity exists in the

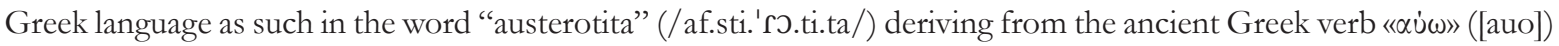
that means "to dry up." It translates into strictness, harshness, rigidity, stringency. For example, one can talk about an "austere teacher" or "austere rules" "austere measures" but not about "austerity measures." In Greek, the word "litotita» $([\lambda \iota \tau \dot{\delta} \tau \eta \tau \alpha])$ is used instead of the term «austerity» to refer to the cutthroat measures. "Litotita" resonates with simplicity, frugality, and ascetism. Outside the crisis context, the term does not necessarily have a negative connotation resonating with living a simple life, not spending much, and a detachment from material goods and consumerism. The linguistic dialectics of the latin/anglo "austerity"2 (latin "austeritas") versus the Greek "litotita" are interesting because austerity is always imposed (it needs a subject and an object) but litotita is usually lived, often even as a personal choice. In addition, austerity has an implied connotation of discipline. It needs an "object" that is going to be disciplined because they did something wrong. The same is not true for the Greek term "letotis" since there is no punitive dimension to its significations. The manufactured neoliberal narrative then, presents austerity as "the payback for something called the 'sovereign debt crisis,' supposedly brought on by states that apparently 'spent too much"' (Seymour, 2014, p. 18) which is an absolute misrepresentation of the facts. According to Seymour "these problems, including the crisis in the bond markets, started with the banks and will end with the banks" (p. 18).

I made the case earlier that austerity resonates with neoliberal necropolitics and I will now turn to the ways austerity translates in terms of human consequences, beyond the discursive level. At this point I would also like to make the argument that austerity is straightforward class politics since "the effects of austerity are felt differently across the income distribution. Those at the bottom of the income distribution lose more than those at the top for the simple reason that those at the top rely far less on government-produced services and can afford to lose more because they have more wealth to start with" (Blyth, 2013, p. 20).

The impact of austerity, according to Seymour (2014), is comparable in some respects to a major war: a catastrophic decline in GDP, such that a projected -3.8 per cent growth in 2013 was considered an improvement on expectations; a drastic and unprecedented fall in the live birth rate of almost 15 per cent; [...] and working class Greeks forced to scavenge for food or queue at soup kitchens as a result of four years of sustained fiscal contraction" (p. 101). Right now Greece is actually worse off than the United States during the Great Depression in 1933 (Alderman, Buchannan \& Porter, 2015). For instance, unemployment in 1933 in the U.S. was at 26\% while 
official accounts put unemployment in Greece right now at 28\% with unofficial accounts exceeding 30\% (with 50\% among those under 25). The irony here is that the IMF, one of the main players in the Greek crisis was supposedly established in order to prevent another Great Depression like the one of the $1930 \mathrm{~s}$.

Greece has experienced 25\% drop in gross domestic product, a $28 \%$ reduction in public sector employment, $28,5 \%$ drop in food consumption, $61 \%$ drop in the average pension down to 833 Euros with $45 \%$ number of pensioners living under the poverty line (The Guardian, 2015). According to the Hellenic Statistics Authority (2015), in $2014,36 \%$ of the population lived in the poverty threshold. The risk of poverty or social exclusion rose in the ages between 18 and 64 to $40 \%$. The threshold of poverty is set at 4,608 Euros annual income per person and 9,677 Euros for a household of two adults and two dependents under the age of 14 . It is estimated that 888,452 out of a total of 2,266,745 households are at risk of poverty which amounts to 2,384,035 people out of 10,785,312 the general population of Greece. There are 1,165,000 or 19.4\% of people living in households where not one member is employed or who is employed for no more than three months. There is an increase in the percentage of households that cannot afford to provide their children either with one meal with meat, chicken or fish at least once a day (8.9\% in 2014 from 4.0\% in 2009), or with fruits and vegetables once a day (5.3\% in 2014 from 1.1\% in 2009). Again Blyth is on point when he notes that the "Greek state is slashing itself to insolvency and mass poverty while given ever-more loans to do so" (2013, pp. 14-15). Unfortunately, by the time austerians realize that this model is not working once more, we will have a Greek population at the brink of extinction. The self-labeled "leftist" government of Syriza has been carrying on the same catastrophic austerity politics that not only have further relegated people in the poverty ranks but have severely undermined the country's national sovereignty and assets.

\section{The Discourse of Disobedience}

In 2010 when Greece was forced to resort to the IMF mechanism, it was portrayed as the "rebel of the European south": the misbehaving kid of the EU, a disobedient country with unlawful, unruly and disorganized citizens who were in need of discipline. The "discipline" and "civilizing mission" in neocolonial terms, came from the lawabiding, protestant European North (Germany mostly) and has been used as a tool for "growth," "progress," and alignment with the other "orderly" European member states. Largely constructed by Greek and European media, fiscal and civil disobedience were used as an excuse for bringing in the IMF and the ECB as policing mechanisms that would straighten things up and bring order back. This loss of national sovereignty was aptly illustrated once more during the fourteen days of "disobedience," the time between the Greek referendum and Syriza's capitulation. The representation of the disobedient Greek has re-emerged after the July 5th 2015 referendum when the landslide victory of "no," was not registered as a clear articulation of the will of the people and their discontent with ongoing austerity, but rather as a rebellion or defection from the European family.

Six years of impoverishment, misery, illness, malnutrition, suicides, and alcoholism, without any welfare state safety nets brought Greek people to their knees in a developed-world humanitarian crisis. The referendum was a space to articulate a clear voice against the ongoing austerity but the disdain of the EU cancelled it out. Popular vote was also cancelled out and thrown in the trashcan a few days later in a series of treasonous decisions and the full capitulation of the Syriza government. As a result, the freedom to decide on the affairs of their polis has been taken away from the Greek people. In the dominant narrative of Greeks who "lived beyond their means," austerity was not simply promoted as a "financial solution" but mostly as a punishment: "The narrative goes as follows: for years, this country's irresponsible and corrupt rulers offered citizens unaffordable perks, instead of reforming taxes; it allowed inefficient and uncompetitive practices to flourish in its state sector instead of disciplining labour markets; and above all, it borrowed beyond its means" (Seymour, 2014, p. 102).

Austerity has been constructed on the premise of fear for the worse not on the promise for a better life. Austerity has further fed into the narrative of good versus bad European citizens, obedient versus disobedient, lazy south versus hard working north and so forth. This polarization has created a two-tiered Europe: Those countries who suffer the Brussels-inspired austerity, that is, the lazy south's Portugal, Spain, Greece plus Ireland (also known as P.I.G.S), versus the responsible, hard-working North, those who pick up the bill, who have always been good citizens, the Germans, Dutch, and Finns. A parallel and persistent narrative to that of unruly Greeks has been that of "living beyond one's means." Greeks have been portrayed in national and international media as spending more than they earn, including other countries' and taxpayers' money and living as parasites sucking off resources 
from "developed Europe." The deep corruption in Greek politics can hardly start to explain the current financial situation. It is interesting to note that in this case the Greek crisis acquired a human face, albeit an ugly one: the disobedient, parasitic, inert Greek. The financial irresponsibility burdens individuals and the state equally. Both need to be disciplined and punished. However, this is an absolute misrepresentation since, according to OECD, "the average Greek worked 2,120 hours in the crisis year of 2008. That is 690 hours more than the average German, 467 hours more than the average Briton and 356 more than the OECD average" (cited in Pogatsa, 2014). Looking at the average number of hours that a person works each week in the EU in 2012, Greeks worked on average more than anyone else. The average working week in Greece is 40.9 hours, compared to 37.2 hours in Spain, 37.9 hours in Portugal, 36.6 hours in France, 35.5 hours in Germany and 34.6 hours in Denmark. Indeed, the Greek working week is substantially longer than both the European Union average week at 36.7 hours and the Euro-area average week at 36.2 hours (Katsikas \& Filinis, 2013). Greeks work on average 1,824 hours per year, or 125 more hours than the Dutch, 165 more hours than the Germans and 250 more hours than the French do (Ibid).

Greeks on average also have fewer vacation days per year and retire later than both the British and the Germans. The expenditure of the Greek state in relation to GDP was actually lower rather than higher than the Eurozone average before the crisis, and significantly lower than that of Germany's (Zafiropoulos 2015). Furthermore, contrary to another persistent myth, Greek public servants did not receive significantly greater levels of compensation compared to the European average. However, public servants have been vilified and anything public has been discredited as dysfunctional. Doreen Massey notes that "in the 1950s the adjective 'public' (worker, sector, sphere) designated something to be respected and relied upon [...] It took a labour of persistent denigration of 'the public' to turn things around. And that labour has been crucial to the ability to pursue the economic strategies we are currently enduring."

Social spending in Greece was significantly lower than the European average.

These numbers hardly justify the portrayal of Greeks as the lazy grasshoppers of the European Union, especially if we take into consideration the fact that Greek salaries are now among the lowest in the EU.

The kind of obedience required by the "disciplined" European North requires an "authoritarian conscience", that is, the internalized voice of an authority, the obedience to outside thoughts and power, one that tends to debilitate "humanistic conscience," that is, our intuitive knowledge to know what's human and inhuman, the ability to be and to judge oneself, the voice that calls us back to ourselves and to our humanity (Fromm, 1981, p. 7). In other words, it requires of Greek people to submit to their own destruction, submit their national sovereignty, sell off their country, lose the capacity to disobey, so they are not even aware of the fact that they obey. Fromm uses two telling examples, the myths of Adam and Eve on one hand, and Prometheus on the other, who, through their disobedience started human history. He claims that humans developed spiritually and intellectually exactly because they were able to say no to the powers that be; therefore, submission to the same powers can only mean spiritual and intellectual death. As a result, says Fromm, (1981) "human history begun with an act of disobedience, and it is not unlikely that it will be terminated by an act of obedience" (p. 1). Here we need to understand that obedience and disobedience are in a dialectical relationship as illustrated, for example, in Antigone's story: by disobeying the inhuman laws of the State, she obeyed the laws of humanity. Every act of disobedience includes an act of obedience to something else. In a very real sense, this kind of disobedience is connected with a notion of human agency; In the collective consciousness disobedience sets people free, embodies what it means to be human. In the dominant narrative, it robs people of their humanity and automatizes them. Greeks, with few exceptions (anti-fascist movements, anti-capitalist left frontal movements, solidarity groups and so forth) have been complicit in their own dehumanization because obeying makes them feel safe and protected: "my obedience makes me part of the power I worship and hence I feel strong. I can make no error since it decides for me" (Fromm, 1981, p. 8). There is a notion among Greek people that if they obey they will avoid the worst, being unable to see themselves as actually living the worst. Neoliberal authoritarian political systems continue to make obedience the human cornerstone of their existence and a perfect system of manufacturing consent.

\section{Conclusion}

Given the rapacity and aggression with which neoliberal policies are being implemented, there is in Greece a kind of "psychologically unmoored" and "physically uprooted" population (Klein, 2008, p. 25) in a very vulnerable 
position. They are the recipients of the catastrophic consequences of austerity and they are the ones doing all the "sacrifices." The EU, the ECB and the IMF together with a complacent Greek government have attempted to establish obedience in Greece by sheer force in the form of economic strangulation, as well as through political blackmail and by capitalizing on Greek people's fear. In order to go forward with "order building," free-market ideologues need to create the perfect setting for their financial ambitions. Both fear and force have been used in the Greek context to preserve obedience and consent. Violent austerity measures have been voted on and implemented not only as "punishment," but also packaged as "sacrifice." However, sacrifice has been projected in the name of avoiding the worse, not as a promise for a better future. Bare individual survival has become the golden standard in neoliberal societies. The neoliberal subject is a deeply individualistic, cruel and egotistic individual. It is a person who becomes complacent to his/her own destruction. Just before a new round of austerity measures, "leftist" prime minister Alexis Tsipras "assured" that "these sacrifices will be the last ones" and that this will be the last round of austerity policies his government will be "forced" to implement. His initial electoral campaign slogan "no sacrifice for the Euro" seemed to have become "any and all sacrifice to remain in the Euro and the EU." Here, however, we need to identify who is the subject of those sacrifices. The burden once more falls on the shoulders of the working class, salaried employees, pensioners, and young people. Ongoing austerity has created a massive underclass that barely survives, is psychologically exhausted and politically disillusioned. The "leftist" management of neoliberal politics since February 2015 has by and large shut down popular resistance.

Syriza came to power in February 2015 campaigning with the slogan "hope is coming." Their message seemed "simple" and was short: "After five years of destruction and fear that led nowhere, it is time for change. With dignity, justice, and democracy, Greece is moving forward, Europe is changing, hope is coming." One of the biggest illusions in this message was the belief that Syriza would be able, as a reformist left party (and even this label is debatable), amidst a climate of political and economic blackmail in the EU to shift the political balance both nationally but also in Europe through negotiations. The July 2015 tour de force on EU's part that led to the full capitulation of the Syriza government, as well as the recent Brexit vote palpably demonstrate that hope cannot survive in the context of an undemocratic, authoritarian and vindictive Europe; A Europe that seems to have forgotten its violent colonial histories, and now repeats its cruel colonial practices to its member-states; A Europe that has never existed as a "family" to all European peoples; A Europe that requires more sacrifices than grants rights and freedoms in the name of being labeled "European." In other words, hope cannot survive within the EU context. It also showed that any type of "hope" cannot survive without a massive, well-organized, politically conscious, and goal-driven popular movement; and that change and rupture do not come through electoral politics and by switching the political management to another party-even if it is a "left" party. The new austerity packages that have been agreed upon, have pushed Greek people further into economic and psychological depression barring any glimpse of hope in the near future. The Greek welfare state will be destroyed down to its root, and the public good will disappear as people will be pushed to their psychological and physical limits: such are the necropolitics of neoliberalism and they cannot be fought with an abstract promise of reformist politics in the name of addressing the humanitarian crisis while implementing a neoliberal program dressed in social welfare language, as Syriza does. It has been one year since the July 5th 2015 referendum when Greek people overwhelmingly had voted "No" to the continued austerity and to the financial and political strangleholds imposed by the European Union, the European Central Bank and the International Monetary Fund since 2010. In the first referendum in the country in 40 years, (the last one in 1974 ousted monarchy) 61,3\% of Greeks voted "no to the lenders' proposals" that would subjugate the country to new Memoranda of Understanding, in exchange for "guaranteeing" cash flow in the form of new debts. It took less than one year for the Syriza government to turn the "no" vote into a "yes." Syriza aligned itself politically with the previous neoliberal governments, signed a third memorandum and, essentially, carried on the austerity attack in an even more violent scale than before. Their discourse was literally one of "creative destruction" since they continued the wholesale of the country and its people, implementing violent austerity while maintaining a "leftist" discourse of social sensibility. Such are the times of neoliberal leftism. 


\section{Endnotes}

1. Here I am expanding on Seymour's discussion, see Seymour, R. (2014). Against Austerity: How we can Fix the Crisis they Made. New York: Pluto Books.

2. Note here that French (austerité) and Spanish (austeridad) also draw from the same Latin word.

\section{References}

Alderman, L., Buchanan, L., Porter E., \& Russel, K. (2015, July 9). Is Greece Worse Off that the U.S. During the Great Depression? The New York Times . Retrieved from http:// www.nytimes.com/interactive/2015/07/09/business/international/is-greece-worse-off-than-the-us-during-the-great-depression.html?smid=tw-nytimes\&_r=1

Bello, W. (2013). Capitalism's Last Stand. New York, NY: Zed Books

Blyth, M. (2013) Austerity: The History of a Dangerous Idea. Oxford University Press, USA.

Blyth, M. (2013, May/June) The Austerity Delusion. Foreign Affairs Magazine . Retrieved from https://www.foreignaffairs. com/articles/2013-04-03/austerity-delusion

European Union. The History of the European Union. Retrieved from http://europa.eu/about-eu/eu-history/index_en.htm

Fromm, E. (1973). The anatomy of human destructiveness . New York, NY: Henry Holt.

Fromm, E. (1976). To have or to be? New York, NY: Continuum.

Fromm, E. (1978). The revolution of hope. Athens, Greece: Boukoumanis.

Fromm, E. (2010/1981). On disobedience. New York, NY: Harper Perennial.

Flassbeck, H. \& Lapavitsas, C. (2015). Against the Troika: Crisis and Austerity in the Eurozone. London: Verso.

Gounari, P. (2014). "Neoliberalism as Social Necrophilia: Erich Fromm and The Politics of Hopelessness in Greece." In Kress, T. \& Lake, B. (Eds.) Reclaiming the Sane Society: Essays on Erich Fromm. NY: Springer, 2014.

Gounari, P. (2012). Neoliberalizing higher education in Greece: new laws, old free-market tricks." In Power and Education, 4(3), pp. 278-289.

Gounari, P. (2006). Contesting the Cynicism of Neoliberal Discourse: Moving Towards a Language of Possibility. In Studies in Language and Capitalism, 1, pp. 77-96.
Hellenic Statistical Authority (EL.STAT) http://www.statistics.gr/ portal/page/portal/ESYE/BUCKET/A0802/PressReleases/ A0802_SFA10_DT_AN_00_2014_15_F_EN.pdf

Holborow, M. (2015). Language and Neoliberalism. New York, NY: Routledge.

Inman, P. (2015, June 29). Where did the Greek Bailout Money Go? The Guardian. Retrieved from http://www.theguardian.com/world/2015/jun/29/ where-did-the-greek-bailout-money-go?CMP=twt_gu

International Monetary Fund The IMF at a Glance. Retrieved from http://www.imf.org/external/about.htm on July 3, 2015.

Katsikas, D. \& Filinis, K. (2013). "Greeks are Lazy and Unskilled" in Dervis, K. et al. Greek Myths and Reality. Hellenic Foundation for European and Foreign Policy \& Brookings Institute.

Klein, N. (2008). The Shock Doctrine. New York: Henry Holt.

Krugman, P. (2015a, July 2015). Killing the European Project. The New York Times. Retrieved from http://krugman.blogs. nytimes.com/2015/07/12/killing the-european-project/?module $=$ BlogPost - Title\&version $=$ Blog\%20Main $\&$ content Collection $=$ Opinion $\&$ action $=$ Click \&pgtype $=$ Blogs\&re gion=Body\&_r $=1$

Krugman, P. (2015b, April 29). The Austerity Delusion. The Guardian. Retrieved from http://www.theguardian.com/ business/ng-interactive/2015/apr/29/the-austerity-delusion

Krugman, P. (2013, November 22). Structural Problems with economese. The New York Times. Retrieved from http://krugman.blogs.nytimes.com/2013/11/22/ structural-problems-with-economese/?_r $=0$

Kwasniewski, N. (2015, July 15). Vorschläge der Euro-Gruppe: Der Katalog der Grausamkeiten. Der Spiegel Online . Retrieved from http://www.spiegel.de/wirtschaft/soziales/ griechenland-euro-gruppe-legt-extrem-harte-forderungenvor-a-1043306.html

Leys, C. (2001). Market driven politics: neoliberal democracy and the public interest. London: Verso. 
Marcuse, H. (1964). One-dimensional man. Boston: Beacon Press.

Massey, D. (2013). Vocabularies of the Economy. Retrieved from https://www.lwbooks.co.uk/sites/default/files/01_vocabularieseconomy.pdf.

Pogatsa, Z. (2014). The political economy of the Greek crisis. LuxSit Publications.

Rucker, P. (2011, August 11). Mitt Romney says "corporations are people." The Washington Post. Retrieved from http://www. washingtonpost.com/politics/mitt-romney-says-corporations-are-people/2011/08/11/gIQABwZ38I_story.html

Seymour, R. (2014). Against austerity: how we can fix the crisis they made. New York: Pluto Books.

Spiegel, P. (2015, July 16). Greece: Donald Tusk warns of extremist political contagion. The Financial Times. Retrieved from http://www.ft.com/intl/cms/s/0/f6872342-2bd2-11e5acfb-cbd2e1c81cca.html\#axzz3gVZuecwt
Stiglitz, J. (2015, July 20) L'Allemagne n'a ni bon sens economique ni compassion. La Liberation . Retrieved from http:// www.liberation.fr/monde/2015/07/15/joseph-stiglitz-l-allemagne-n-a-ni-bon-sens-economique-ni-compassion_1348536

The Guardian . (2015, June 18). Front Page.

Word of the Year (2010, December 20). Retrieved from http:// www.merriam-webster.com/word-of-the-year/2010-word-ofthe-year.htm

Zafiropoulos, P. (2014, March 13). Busting the Myth of What Caused the Greek Crisis and why Austerity won't work. The Press Project . Retrieved from http://www.thepressproject. net/article/58136/Ignoring-the-data-about-Greeces-debtwhy-austerity-is-based-on-a-myth-and-will-not-work 